\title{
SOIL PROPERTIES AND EARTHWORM DYNAMICS AFFECTED BY LAND USE SYSTEMS IN WESTERN CHITWAN, NEPAL
}

\author{
R.P. Chauhan ${ }^{1}$, K.R. Pande ${ }^{2}$, S.C. Shah ${ }^{1}$ and D.D. Dhakal ${ }^{1}$ \\ ${ }^{1}$ Institute of Agriculture and Animal Sciences, Tribhuvan University, Nepal \\ ${ }^{2}$ Agriculture and Forestry University, Chitwan, Nepal
}

\begin{abstract}
Field experiments were conducted in acidic soils of Mangalpur and Fulbari Village Development Committees in western Chitwan, Nepal to study the effects of different land use systems on soil properties and earthworm dynamics. Seven land use systems (cereal based lowland, cereal based upland, vegetable farm land, fruit orchard land, pasture land, forest land and farmer's field) were used and they were replicated four times in randomized complete block designs. Soil organic matter and total soil nitrogen were significantly higher from pasture land $(4.7 \%$ and $0.2 \%)$ and the lowest were from farmer's field (2.4\% and $0.1 \%)$. However, available soil phosphorous content was significantly higher from cereal based upland $\left(448.3 \mathrm{~kg} \mathrm{ha}^{-1}\right)$ and it was the lowest from forest land $\left(13.0 \mathrm{~kg} \mathrm{ha}^{-1}\right)$. The highest earthworm count was observed from pasture land (10.1 numbers per trap) than others but it was the lowest from farmer's field. There were significant positive correlations between soil organic matter content and the earthworm count $\left(\mathrm{r}=0.96^{* *}\right)$ and between total soil nitrogen content and earthworm count $\left(\mathrm{r}=0.80^{* *}\right)$. In contrast, a significant negative correlation was observed between earthworm count and available $\mathrm{P}\left(\mathrm{r}=-0.51^{* *}\right)$. Correlation between earthworm count and silt content was positive $\left(\mathrm{r}=0.68^{* *}\right)$ but between earthworm count and sand content was negative $\left(\mathrm{r}=-0.64^{* *}\right)$. However, there were no significant relationships of earthworm count with available $\mathrm{K}, \mathrm{pH}$, bulk density and clay content of soils. The soil organic matter, total soil nitrogen and earthworm count were higher from pasture soil than other soils. As soil organic matter, total soil $\mathrm{N}$, available soil $\mathrm{P}$ and soil texture regulated earthworm dynamics in soils. Earthworm population may be used as a bioindicator of soil fertility status and it can be developed as an alternative technique for soil fertility evaluation after quantification and verification from further experiments on earthworm dynamics under different land use systems.
\end{abstract}

Key words: land use systems, earthworm dynamics, bio-indicator, soil fertility evaluation

\section{INTRODUCTION}

Soil is vital to life and thus called 'the greatest heritage of mankind'. Humans were historically dependent on hunting and gathering of food to sustain life. With the increase in human population, organized agricultural systems were needed to ensure food security. Earthworms are important organisms doing a great job in the soil for mankind over thousands of year. There are about 3,627 species of terrestrial earthworms in the world (Reynolds, 1994). In Nepal only four kinds of earthworm have been recorded (Tamrakar, 2012). Earthworms improve soil physical, chemical and biological properties and add nutritive value to the soil for healthy crop production due to their feeding habit (Lavelle, 1988 and Jones et al., 1994). Earthworms stimulate soil organic matter mineralization and increase nutrient availability (Brown et al., 2004a). Increased human activities caused by increase in population density had been altering the agricultural landscape in Southeast Asia over the last two decades. Land use changes directly affect the biotic diversity (Sala et al., 2000). The changes in land use affect the diversity and population of earthworms associated with change in the natural habitat. Many researchers reported that SOM, NPK, soil texture and $\mathrm{pH}$ frequently regulated the earthworm population. Plant behavior and expression of deficiency by phenotypic characters (deficiency symptoms), analysis of plant tissue and soil test are the major soil fertility evaluation techniques (Brady, 2005). These techniques have their own merits and demerits and also cannot be afforded by 
most of the Nepalese farmers. Hence, an alternative technique of soil fertility evaluation is crucial for small and marginalized farmers. Diversity and density of earthworms could be indicators of soil fertility status of different land uses. There may be an opportunity to develop an alternative technique of soil fertility evaluation by taking earthworm abundance as a bench mark. This might be the cheapest and easily accessible technique for all the farmers. However, the effects of soil physicochemical properties on earthworm abundance have not yet been studied. The present study intended to establish relationships between earthworm dynamics and soil properties.

\section{MATERIALS AND METHOD}

Seven land use systems: cereal based lowland, cereal based upland, vegetable farm land, fruit orchard land, pasture land, forest land and farmer's field of Mangalpur and Fulbari VDCs of Chitwan district were used as treatments. Each treatment was replicated four times in four separate fields except for pasture and forest lands. Pasture and forest lands were replicated in four different blocks separated by Seti Devi Community Forest executive body. The whole experiment was designed in a randomized complete block design. There were total of twenty eight study sites. At each, earthworm populations were quantified for five months at one month intervals, using a specially designed earthworm attraction unit. Soil samples from 0-20 cm depth from the soil surface were collected from each study site. The data obtained were analyzed using MSTAT-C. Duncan Multiple Range Test and correlations as a measure of inferential statistics were also used for data analysis. Correlation coefficients were calculated using SPSS.

\section{RESULTS AND DISCUSSION \\ Effect of land use systems on soil physicochemical properties}

Soil texture was affected by land use and land management. Significantly higher silt $(47.3 \%)$ and clay $(18.3 \%)$ contents were observed from the forest soils than other land use systems. Cereal based upland soils had higher sand content (69.4\%) than other land use systems. However, there was not significant effect of land use systems on bulk density of the soil.

Table 1. Soil physical properties under different land use systems of western Chitwan, Nepal, 2013

\begin{tabular}{llllll}
\hline Land use systems & $\begin{array}{l}\text { Sand } \\
(\%)\end{array}$ & $\begin{array}{l}\text { Silt } \\
(\%)\end{array}$ & $\begin{array}{l}\text { Clay } \\
(\%)\end{array}$ & $\begin{array}{l}\text { Bulk Density } \\
\left(\mathrm{g} \mathrm{cm}^{-3}\right)\end{array}$ & $\begin{array}{l}\text { Soil Textural } \\
\text { Class }\end{array}$ \\
\hline Cereal based lowland & $59.7^{\mathrm{b}}$ & $25.4^{\mathrm{bc}}$ & $14.9^{\mathrm{ab}}$ & 1.3 & Sandy loam \\
Cereal based upland & $69.4^{\mathrm{a}}$ & $20.5^{\mathrm{d}}$ & $10.1^{\mathrm{c}}$ & 1.4 & Sandy loam \\
Vegetable farm land & $67.5^{\mathrm{a}}$ & $22.4^{\mathrm{cd}}$ & $10.2^{\mathrm{c}}$ & 1.3 & Sandy loam \\
Fruit orchard land & $58.8^{\mathrm{b}}$ & $27.7^{\mathrm{b}}$ & $13.6^{\mathrm{bc}}$ & 1.2 & Sandy loam \\
Pasture land & $35.9^{\mathrm{c}}$ & $46.9^{\mathrm{a}}$ & $17.1^{\mathrm{ab}}$ & 1.0 & Loam \\
Forest land & $34.4^{\mathrm{c}}$ & $47.3^{\mathrm{a}}$ & $18.3^{\mathrm{a}}$ & 1.2 & Loam \\
Farmer's field & $57.7^{\mathrm{b}}$ & $26.9^{\mathrm{b}}$ & $15.5^{\mathrm{ab}}$ & 1. & Sandy loam \\
\hline LSD $(0.05)$ & $5.29^{* *}$ & $4.28^{* *}$ & $3.77^{* *}$ & $\mathrm{NS}$ & \\
SEM ( \pm ) & 1.78 & 1.44 & 1.27 & 0.14 & \\
Grand Mean & 54.77 & 31.00 & 14.23 & 1.27 & 22.32 \\
CV $(\%)$ & 6.51 & 9.29 & 17.83 & 2.32 & \\
\hline
\end{tabular}

Means followed by the same letter in a column are not significantly different at $5 \%$ level of significance as determined by DMRT 
The highest amount of soil organic matter $(4.7 \%)$ was recorded from the pasture land whereas the lowest (2.4\%) was from the farmer's field (Table 2). The lower levels of SOM from farmer's field, cereal based upland, cereal based lowland and vegetable farm land could be the result of high OM decomposition, insufficient organic materials inputs in the systems, residue removal and lack of crop rotation (Duff et al., 1995 and Grace et al., 1995). Clay particles adsorbed and stabilized more OM and other nutrients (Saggar et al., 1994 and 1996) in pasture and forest lands.

Table 2. Soil chemical properties under different land use systems of western Chitwan, Nepal, 2013

\begin{tabular}{lclccc}
\hline Land use systems & $\mathbf{S O M}(\%)$ & $\mathbf{N}(\%)$ & $\mathbf{P}_{2} \mathbf{O}_{5}\left(\mathbf{k g ~ h a}^{-1}\right)$ & $\mathbf{K}_{2} \mathbf{O}\left(\mathbf{k g ~ h a}^{-1}\right)$ & $\mathbf{p H}$ \\
\hline Cereal based lowland & $3.0^{\text {cd }}$ & $0.13^{\mathrm{c}}$ & $17.0^{\mathrm{c}}$ & 27.3 & 5.5 \\
Cereal based upland & $2.8^{\mathrm{cd}}$ & $0.09^{\mathrm{d}}$ & $448.3^{\mathrm{a}}$ & 90.0 & 5.6 \\
Vegetable farm land & $2.6^{\mathrm{d}}$ & $0.15^{\mathrm{c}}$ & $375.3^{\mathrm{a}}$ & 86.5 & 5.4 \\
Fruit orchard land & $3.8^{\mathrm{b}}$ & $0.18^{\mathrm{b}}$ & $83.8^{\mathrm{bc}}$ & 120.5 & 5.7 \\
Pasture land & $4.7^{\mathrm{a}}$ & $0.23^{\mathrm{a}}$ & $15.3^{\mathrm{c}}$ & 72.8 & 5.7 \\
Forest land & $3.4^{\mathrm{bc}}$ & $0.19^{\mathrm{b}}$ & $13.0^{\mathrm{c}}$ & 79.5 & 5.4 \\
Farmer's field & $2.4^{\mathrm{d}}$ & $0.08^{\mathrm{d}}$ & $119.3^{\mathrm{b}}$ & 88.3 & 5.2 \\
\hline LSD (0.05) & $0.64^{* *}$ & $0.02^{* *}$ & $83.54^{* *}$ & $\mathrm{NS}$ & $\mathrm{NS}$ \\
SEM ( \pm ) & 0.22 & 0.01 & 28.12 & 26.23 & 0.24 \\
Grand Mean & 3.24 & 0.15 & 153.11 & 80.68 & 5.51 \\
CV $(\%)$ & 13.39 & 8.70 & 36.73 & 65.01 & 8.66 \\
\hline
\end{tabular}

Means followed by the same letter in a column are not significantly different at $5 \%$ level of significance as determined by DMRT

Nitrogen content of soil was significantly affected by the land use systems. Total soil nitrogen content was the highest $(0.23 \%)$ from pasture land and the lowest $(0.08 \%)$ was from farmer's field (Table 3). Runquan (2002) reported a decrease in soil organic matter and total nitrogen due to deforestation. $\mathrm{Fu}$ et al. (2001) also found $18 \%$ increment in total soil $\mathrm{N}$ when farm lands were converted back to forest land.

The highest available phosphorous $\left(448.3 \mathrm{~kg} \mathrm{ha}^{-1}\right)$ was recorded from the cereal based upland and that of the lowest $\left(13 \mathrm{~kg} \mathrm{ha}^{-1}\right)$ was observed from the forest land. P fixation is greater in soil having higher clay content (Havlin et al., 1990) and this might be the reason for low level of available $\mathrm{P}$ from the pasture land, forest land and cereal based lowland. Low levels of available P from the forest soil might also be due to the forest vegetation itself with large biomass and thus more $\mathrm{P}$ uptake and immobilization in plant biomass. Phosphorous shows a tendency to build up in soil with subsequent addition of phosphatic fertilizers from external sources. The residual effect of added phosphatic fertilizers might have caused a high level of phosphorous from the cereal based upland and vegetable farm, but such an effect in the cereal based lowland may have been overridden by the higher clay content.

There were no significant effects of land use systems on the potassium content of the soil. Soils of all the land use systems were slightly acidic in nature ( $\mathrm{pH}$ below 6).

\section{Land use systems effects on earthworms dynamics}

Earthworms dynamic in terms of their abundance were significantly affected by the land use systems. The highest earthworm count (10.1 per trap) in terms of average of the five sampled dates 
was recorded from the pasture land and the lowest (3.3) from the farmer's field (Table 3). Highest soil organic matter in the pasture land might contribute to supply more feed stuffs to the earthworms and made environment favorable for their multiplication. Lavelle et al. (1999) and Lee (1985) reported that soil organic matter was an important factor governing earthworm variations in different land use systems because soil organic matter was a major food resource for earthworms. Yusnaini et al. (2004) also reported a positive effect on activity and existence of soil organisms with the increase of soil organic matter content. Abundance of earthworm from the pasture and forest soils was also depicted by Edwards and Bohlen (1996). Baker et al. (1992) found a positive correlation between earthworm abundance and clay content. Positive correlation between earthworm abundance and silt content of soil was reported by Hendrix et al. (1992). Thus, the highest amount of clay and silt particles from pasture land (Table 1) might have attributed to the highest earthworm count. Agricultural practices like plowing, multiple tillage, application of chemical fertilizer and pesticides could have reduced the earthworm members in farmer's field besides lower content of soil organic matter.

Table 3. Earthworms abundance under different land use systems in western Chitwan, Nepal, 2013

\begin{tabular}{lc}
\hline Land use systems & Earthworms count per trap \\
\hline Cereal based lowland & $5.2^{\text {cd }}$ \\
Cereal based upland & $4.3^{\mathrm{d}}$ \\
Vegetable farm land & $3.5^{\mathrm{d}}$ \\
Fruit orchard land & $7.8^{\mathrm{b}}$ \\
Pasture land & $10.1^{\mathrm{a}}$ \\
Forest land & $6.5^{\mathrm{bc}}$ \\
Farmer's field & $3.3^{\mathrm{d}}$ \\
\hline LSD $(0.05)$ & $1.70^{* *}$ \\
SEM $( \pm)$ & 0.58 \\
Grand Mean & 5.79 \\
CV $(\%)$ & 20.10 \\
\hline
\end{tabular}

\section{Relationship between soil properties and earthworm dynamics}

Soil properties frequently regulate earthworm abundance and distribution in different land use systems (Edwards and Bohlen, 1996). Earthworm dynamic was significantly regulated by SOM, total soil nitrogen, available $\mathrm{P}$, sand and silt contents.

Table 4. Simple correlation coefficients between soil properties and earthworm counts in western Chitwan, Nepal, 2013

\begin{tabular}{llllllllll}
\hline & $\mathrm{pH}$ & $\mathrm{SOM}$ & $\mathrm{N}$ & $\mathrm{P}_{2} \mathrm{O}_{5}$ & $\mathrm{~K}_{2} \mathrm{O}$ & $\mathrm{BD}$ & Clay & Sand & Silt \\
\hline Earthworms count & 0.23 & $0.96^{* *}$ & $0.80^{* *}$ & $-0.51^{* *}$ & 0.05 & -0.17 & 0.35 & $-0.64^{* *}$ & $0.68^{* *}$ \\
\hline
\end{tabular}

A significant positive correlation $\left(\mathrm{r}=0.96^{* *}\right)$ was recorded between soil organic matter and earthworm count (Table 4). This result was in accordance with the findings of Hendrix et al. (1992) that a strong positive correlation between earthworm population density and soil organic matter content across 10 sites they studied. Schmidt et al. (2004) also recorded an increased earthworm number with the increase in organic carbon content in the Egyptian soil. Soil with low organic matter content cannot support food for higher numbers of earthworms and resulted in their lower count as described by Edwards and Bohlen (1996). 
There was a positive correlation $\left(\mathrm{r}=0.80^{* *}\right)$ between total soil nitrogen and earthworm count, supporting the argument that higher amounts of total nitrogen favored increment in earthworm numbers (Table 4). Application of a large amount of nitro chalk to pastures for grass production increased earthworm numbers (Edwards and Lofty, 1977). The increment in earthworm count with increased total nitrogen might be due to increased vegetative production which in turn increases the amount of residues returned to the soil. The same phenomenon of increment in earthworm number with the addition of chemical nitrogenous fertilizer was reported by Duiker and Stehouwer (2007). Thus, the higher number of earthworm in an ecosystem can be taken as an indicator of higher total nitrogen content in that ecosystem.

Available soil $P$ and earthworm count showed a negative correlation $\left(r=-0.51^{* *}\right)$ as shown in Table 4. Gerard and Hay (1997) also reported a decrease in number of earthworms from grass plots with the application of superphosphate fertilizers. The decreased count of earthworms from soils having higher content of available $\mathrm{P}$ might not be the result of available $\mathrm{P}$ rather it might be due to other soil parameters such as lower amount of soil organic matter, total nitrogen and higher fraction of sands than silt and clay in soils.

A negative correlation $\left(r=-0.64^{* *}\right)$ was observed between sand content and the earthworm count, whereas; silt content and the earthworm count were found to have a positive correlation ( $\mathrm{r}$ $\left.=0.68^{* *}\right)$. Soil texture modifies other soil characteristics like water holding capacity and nutrient status (Edwards and Bohlen, 1996). Higher silt content was responsible for a higher earthworm count. Hendrix et al. (1992) also reported higher earthworm abundance from soils having higher silt contents.

\section{CONCLUSIONS}

Soil properties and earthworm dynamics were significantly affected by the land use systems. Earthworms may be used as bio-indicators to evaluate soil fertility status. Earthworm abundance can be used as an alternative technique for soil fertility evaluation. However, for quantification and verification, both phytotron and field experiments are required for detailed study on earthworm dynamics.

\section{ACKNOWLEDGEMENT}

The authors are thankful to Dean, IAAS; Academic Dean, IAAS; Department of Soil Science and Agricultural Engineering, AUS-AID PSLP project for providing research grant, and farmers who provided study sites.

\section{REFERENCES CITED}

Baker, G.H., V.J. Barrett, R. Grey-Gardner and J.C. Bucker field. 1992. The life history and abundance of the introduced earthworms Aporrectodae trapezoids and Aporrectodae caliginosain pasture soils in the Mount Lofty Range, South Australia. Aust. J. Ecol. 17(2): 177-188.

Brady, N.C. and R.R. Weil. 2005. The nature and properties of soil. $13^{\text {th }}$ ed. New Jersey: PrenticeHall, Inc.887, 902, 905 and 960p.

Brown, G.G., N.P. Benito, A. Pasini, K. D. Sautter, M. Guimaraes and E. Torres. 2004. No-tillage greatly increases earthworm populations in Parana State, Brazil. Pedobiologia. 47: 764-771.

Duff, B., P.E. Rasmussen and R.W. Smiley. 1995. Wheat/fallow systems in semi-arid regions of the Pacific, north-west America. In: V. Barnett, R. Payne and R. Steiner (eds.). Agricultural Sustainability: Economic, Environmental and Statistical Considerations. John Wiley and Sons, Inc., New York. pp. 85-109.

Duiker, S. and R. Stehouwer. 2007. Earthworms. [On-line]. Available: . Retrieve: December 20, 2013. 
Edwards, C.A. and J.R. Lofty 1977.The effects of straw residues and their disposal on the soil fauna. In: R. Willey (ed). Straw decay and its effect on dispersal and utilization. New York. pp. 37-44.

Edwards, C.A. and P.J. Bohlen 1996. Biology and Ecology of Earthworms. $3^{\text {rd }}$ ed. London: Chapman and Hall.

Fu, B.J., X.D. Guo, L.D. Chen, K.M. Ma, and J.R. Li. 2001. Soil nutrient changes due to land use changes in Northern China: A case study in Zunhua County, Hebei Province. Soil Use and Management. 17: 294-296.

Gerard, B.M. and R.K.M. Hay 1997.The effects on earthworms of ploughing, cultivation, direct drilling and nitrogen in a barley monoculture system. J. Agric. Sci. 93: 147-155.

Grace, P.R., J.M. Oades, H. Keith and T.W. Hancock. 1995. Trends in wheat yields and soil organic carbon in the permanent rotation trial at the Waite Agricultural Research Institute, South Australia. Aust. J. Exp. Agric.35: 857-864.

Havlin, J.L., J.D. Beaton, S.L. Tisdale, and W.L. Nelson. 1990. Soil Fertility and Fertilizers: An Introduction to Nutrient Management. $6^{\text {th }}$ ed. Pearson Education Inc. and Dorling Kindersley Publishing Inc. New Delhi, India.

Hendrix, P.F., B.R. Muller, R.R. Bruce, G.W. Langdale and R.W. Parmelee. 1992. Abundance and distribution of earthworms in relation to landscape factors on the Georgia piedmont, U.S.A. Soil Biol. Biochem. 24: 1357-1361.

Jones, C. G., J. H. Lawton, and M. Shachak. 1994. Organisms as ecosystem engineers. Oikos 69: 373-386.

Lavelle, P. 1988. Earthworm activities and the soil system. Biol. Fertil. Soils 6: 237-251.

Lavelle, P., L. Brussaard, and P. Hendrix. 1999. Earthworm Management in Tropical Agro-ecosystems. New York: CABI Publishing.

Lee, K.E. 1985. Earthworms - Their Ecology and Relationship with Soils and Land Use. Sydney, Academic Press.

Reynolds, J.W. and D.C. Cook. 1994. Nomenclature of oligochaetogica. Supplementum secundum. New Brunswick museum monograph No. 9, Canada.

Runquan, H.D. Junhua, H. Xingyi, Panlei and Z. Junzhao. 2002. Jamming effects on soil degradation course in three Gorges reservoir region — regarding the district where soil is originated from efflorescent granite as example. $12^{\text {th }}$ ISCO conference Beijing.

Saggar, S., A. Parshotam, G.P. Sparling, C.W. Feltham and P.B.S. Hart. 1996. ${ }^{14}$ C-labelled rye grass turnover and residence times in soils varying in clay content and mineralogy. Soil Biol. Biochem. 28: 1677-1686.

Saggar, S., K.R. Tate, C.W. Feltham, C.W. Childs and A. Parshotam. 1994. Carbon turnover in a range of allophonic soils amended with ${ }^{14} \mathrm{C}$-labelled glucose. Soil Biol. Biochem. 26: 1263-1271.

Sala, O.E., F.S. Chapin, J.J. Armesto, E. Berlow, J. Bloomfield, R. Dirzo, E. Huber-Sanwald, L.F. Huenneke, R.B. Jackson, A. Kinzig, R. Leemans, D.M. Lodge, H.A. Mooney, M. Oesterheld, N.L. Proff, M.T. Sykes, B.H. Walker, M. Walker and D.H. Wall. 2000. Biodiversity: Global biodiversity senarios for the year 2000. Science 287: 1770-1774.

Schmidt, O., J.P. Curry, J. Dyckmans, E. Rota and C.M. Scrimgeour. 2004. Dual stable isotope analysis of soil invertebrates and their food sources. Pedobiologia 48: 171-180.

Tamrakar, A.S. 2012. June. Earthworm conference. Kathmandu, Nepal

Yusnaini, S., M. Utomo and M.A.S. Arif. 2004. Effect of long-term conservation tillages and nitrogen fertilization on soil mesofauna and earthworms. In: F.X. Susilo, A. Gafur, M. Utomo, R. Evizal, Murwani. and I.G. Swibawa (eds.). Conservation and sustainable management of Belowground Biodiversity in Indonesia. Universitas Lampung. Pp.19-25. 